\title{
Upaya Meningkatkan Hasil Belajar Fisika Melalui Pemahaman Konsep Tentang Teori Kinetik gas dengan Metode Diskusi dan Tanya Jawab pada Siswa Kelas XI IPA MAN 2 Pontianak Tahun 2009
}

\author{
Suminem dan Siti Khaeriyah \\ MAN 2 Kota Pontianak, Dinas Pendidikan Kota Pontianak
}

\begin{abstract}
Abstrak
Penelitian Tindakan Kelas (PTK) ini bertujuan untuk meningkatkan prestasi belajar sains (Fisika) siswa dengan menerapkan melalui pemahaman konsep tentang teori kinetik gas dengan metode diskusi dan tanya jawab pada siswa kelas XI IPA Pontianak tahun 2009. Penelitian ini dilaksanakan selama tiga bulan (3 siklus). Subyek dalam penelitian adalah siswa kelas XI IPA tahun pelajaran 2008/2009 Pontianak pengumpulan data melalui ulangan dengan materi Teori Kinetik Gas. Hasil penelitian menunjukkan adanya peningkatan prestasi dan kreatif siswa, hal ini dapat dibuktikan dari hasil ulangan dari siklus 1 sampai ke siklus 3 adanya peningkatan perolehan yang didapat pada siklus ke 3 menunjukkan dari 36 siswa (100\%) telah berhasil .jadi secara umum pembelajaran menggunakan metode diskusi dan tanya jawab dapat meningkatkan hasil belajar siswa.
\end{abstract}

Kata kunci: teori kinetik gas, penelitian tindakan kelas, diskusi dan tanya jawab

\section{Pendahuluan}

Mata pelajaran Fisika memiliki tujuan meningkatkan hasil belajar, dengan demikian mata pelajaran Fisika menjadi penting bagi meningkatkan kualitas sumber daya manusia di kalangan siswa. Namun dalam kenyataannya mata pelajaran ini oleh sebagian besar siswa masih menganggap mata pelajaran Fisika sulit, hal ini terbukti nilai rata - rata siswa masih tergolong rendah.

Banyak faktor yang menjadi penyebabnya, antara lain materi, siswa dan metode. Kenyataannya semua itu perlu dicarikan solusinya, salah satunya adalah dengan memberikan pemahaman konsep fisika melalui diskusi, tanya jawab, sehingga hasil belajar siswa dapat meningkat sesuai dengan yang diharapkan.

Berkaitan dengan itu penulis tertarik untuk mengetahui lebih jauh konsep tersebut, yaitu tentang Teori Kinetik Gas melalui pemahaman konsep dengan metode diskusi dan tanya jawab pada siswa kelas XI IPA

Menurut Kauchack dan Eggen (1993) pada saat akan mengajarkan sebuah keterampil-an kompleks guru harus terlebih dahulu membagi - bagi suatu topik atau suatu keterampilan menjadi bagian - bagian sebagai prasyaratnya. Cara yang dilaku-kan guru tersebut yang disebut task analysis (analisis tugas) proses ini dilakukan oleh guru pada saat merencanakan kegiatan belajar mengajar. Dengan demikian apa yang diharapkan akan tercapai dan pada saat berlangsungnya kegiatan pembelajaran siswa merasa nyaman, senang karena bisa mengikuti serta mendapatkan hasil yang diharapkan.

Sesuai dengan latar belakang di atas yang menjadi masalah penelitian ini adalah : bagaimana meningkatkan pemahaman konsep siswa tentang Teori Kinetik Gas dengan metode diskusi dan tanya jawab pada siswa kelas XI IPA . 
Tujuan penelitian ini adalah untuk mengetahui upaya meningkatkan pemahaman konsep siswa tentang Teori Kinetik Gas dengan metode diskusi dan tanya jawab pada siswa kelas XI IPA.

\section{Pengertian Belajar}

Belajar adalah Suatu perbuatan yang dilaksanakan dari awal sampai akhir sehingga terjadinya perubahan dari tidak tahu menjadi tahu. Menurut Abu Ahmad Hakekat mengajar adalah :

1. menanamkan pengetahuan kepada anak-anak

2. menyampaikan pengetahuan kebudayaan kepada anak.

\begin{tabular}{lrr} 
Suatu aktivitas mengatur \\
lingkungan sebaik-baiknya dan \\
menghubungkan dengan anak didik \\
sehingga terjadi proses belajar. \\
\multicolumn{2}{c}{ Jadi Hakekat Belajar menurut Abu }
\end{tabular}
Ahmad adalah Usaha sadar untuk menguasai ilmu, untuk dapat menerapkan dan mengajar saling berkaitan dalam suatu proses menuju perubahan pengetahuan. Jadi belajar adalah suatu proses perubahan tingkah laku yang potensial terhadap situasi tertentu yang dapat diperoleh dari pangalaman yang dilakukan secara berulang-ulang. Hilgard, (1981). Jadi HAKEKAT belajar adalah usaha sadar untuk mengusai ilmu , untuk dapat menerapkan pengetahuan, untuk dapat melaksanakan suatu pekerjaan yang baik. Belajar dan mengajar saling berkaitan dalam suatu proses menuju perubahan pengetahuan, perubahan tingkah laku, perubahan keterampilan dan dapat mengatasi persoalan hidup dengan baik dan mandiri. Menurut Inger (1980), belajar adalah perubahan-perubahan perilaku yang potensial tercermin sebagai akibat dari latihan dan pengalaman masa lalu terhadap situasi tugas tertentu. Belajar menurut pendapat para ahli lain adalah perubahan tingkat laku atau perubahan kecakapan yang mampu bertahan dalam waktu tertentu dan bukan berasal dari proses pertumbuhan.
Menurut Piaget, bahwa belajar akan lebih berhasil apabila disesuaikan dengan tahap perkembangan kognetif peserta didik. Peserta didik hendaknya diberi kesempatan untuk melakukan eksperimen berdiskusi dengan obyek siswa, yang ditunjang oleh interaksi dengan teman sebaya dan dibantu oleh pertanyaan guru. Guru hendaknya banyak memberikan rangsangan kepada peserta didik agar mau berinteraksi dengan lingkungan secara aktif, mencari dan menemukan berbagai hal dari lingkungan.

\section{Pentingnya Diskusi dan Tanya Jawab}

Metode diskusi adalah suatu usaha untuk memecahkan, memperingan suatu permasalahan dengan cepat dan tepat sehungga mendapatkan hasil yang memuaskan serta memperluas dan menambah wacana tentang pengetahuan secara luas.

Metode tanya jawab adalah: Pernyataan/keterangan/penjelasan ulasan yang disampaikan atau disajikan oleh pihak pertama kepada pihak kedua bisa berupa bahan pelajaran atau yang lainnya kemudian mendapatkan balasan secara teratur dan sistematis.

\section{Hasil dan Pembahasan}

Data hasil penelitian yang diperoleh berupa hasil uji coba item butir soal, data observasi berupa pengamatan pengelolaan belajar aktif dan pengamatan aktivitas siswa dan guru pada akhir pembelajaran, dan data tes formatif siswa pada setiap siklus.

Data hasil uji coba item butir soal digunakan untuk mendapatkan tes yang betul-betul mewakili apa yang diinginkan. Data ini selanjutnya dianalisis tingkat validitas, relia-ilitas, taraf kesukaran, dan daya pembeda. Data lembar observasi diambil dari dua pengamatan yaitu pengamatan pengelolaan belajar aktif yang digunakan untuk mengetahui pengaruh metode yang digunakan dalam 
meningkatkan prestasi belajar siswa dan data pengamatan aktivitas siswa dan guru. Data tes formatif untuk mengetahui peningkatan prestasi belajar siswa setelah diterapkan metode diskusi dan tanya jawab.

\section{Analisis Item Butir Soal}

Sebelum melaksanakan pengambilan data melalui instrument penelitian berupa tes diuji dan dianalisis. Uji coba dilakukan pada siswa di luar sasaran penelitian. Analisis tes yang dilakukan meliputi:

1. Validitas

Validitas butir soal dimak-sudkan untuk mengetahui kelayakan tes sehingga dapat digunakan sebagai instrument dalam penelitian ini. Dari perhitungan 10 soal diperoleh 7 soal tidak valid dan 3 soal valid. Hasil dari validitas soal-soal dirangkum dalam tabel di bawah ini.

Tabel 1. Soal Valid dan Tidak Valid Tes Formatif Siswa

\begin{tabular}{|c|c|}
\hline Soal Valid & $\begin{array}{c}\text { Soal Tidak } \\
\text { Valid }\end{array}$ \\
\hline $1,4,6,7,8,9,10$, & $2,3,5$, \\
\hline
\end{tabular}

\section{Reliabilitas}

Soal-soal yang telah memenuhi syarat validitas diuji reliabilitasnya. Dari hasil per-hitungan diperoleh koefisien reliabilitas $r_{11}$ sebesar 0 , 554. Harga ini lebih besar dari harga $\mathrm{r}$ product moment. Untuk jumlah siswa $(\mathrm{N}=36)$ dengan $\mathrm{r}$ $(95 \%)=0,404$. Dengan demikian soalsoal tes yang digunakan telah memenuhi syarat reliabilitas.

\section{Taraf Kesukaran (P)}

Taraf kesukaran di-gunakan untuk mengetahui tingkat kesukaran soal. Hasil analisis menunjukkan dari 10 soal yang diuji terdapat:

- 4 soal mudah

- 4 soal sedang

\section{- 2 soal sukar}

\section{Daya Pembeda}

Analisis daya pembeda dilakukan untuk mengetahui kemampuan soal dalam membedakan siswa yang berkemampuan tinggi dengan siswa yang berkemampuan rendah.

Dari hasil analisis daya pembeda diperoleh soal yang berkriteria jelek sebanyak 4 soal, berkriteria cukup 4 soal, berkriteria baik 2 soal. Dengan demikian soal-soal tes yang digunakan telah memenuhi syara-syarat validitas, reliabilitas, taraf kesukaran, dan daya pembeda

5. Aktivitas Guru dan Siswa Dalam Pembelajaran

Berdasarkan analisis data, diperoleh aktivitas siswa dalam proses pembelajaran Sains/ Fisika dengan metode diskusi dan tanya jawab yang paling dominan adalah mendengarkan/memperhatikan penjelasan guru, dan diskusi antar siswa/antara siswa dengan guru. Jadi dapat dikatakan bahwa aktivitas siswa dapat dikategorikan aktif. Sedangkan untuk aktivitas guru selama pembelajaran telah me-aksanakan langkah-langkah belajar aktif dengan baik. Hal ini terlihat dari aktivitas guru yang muncul di antaranya aktivitas membimbing dan mengamati siswa dalam mengerjakan kegiatan, menjelaskan, memberi umpan balik/evaluasi/tanya jawab dimana prosentase untuk aktivitas di atas cukup besar.

\section{Simpulan dan Saran}

Dari hasil kegiatan pembelajaran yang telah dilakukan selama tiga siklus, dan berdasarkan seluruh pembahasan serta analisis yang telah dilakukan dapat disimpulkan sebagai berikut:

Pembelajaran dengan Upaya meningkatkan Hasil Belajar Fisika melalui pemahaman konsep tentang Teori 
Kinetik Gas dengan Metode Diskusi dan Tanya Jawab pada siswa Kelas XI IPA memiliki dampak positif dalam meningkatkan prestasi belajar siswa yang ditandai dengan peningkatan ketuntasan belajar siswa dalam setiap siklus, yaitu siklus I (44,44\%), siklus II $(86,11 \%)$, siklus III $(100 \%)$.

Penerapan Upaya meningkatkan Hasil Belajar Fisika melalui pemahaman konsep tentang Teori Kinetik Gas dengan Metode Diskusi dan Tanya Jawab pada siswa Kelas XI IPA mempunyai pengaruh positif, yaitu dapat meningkatkan motivasi belajar siswa untuk mempelajari materi pelajaran yang telah diterima selama ini yang ditunjukan dengan ratarata jawaban siswa yang menyatakan bahwa siswa antusias dengan Upaya meningkatkan Hasil Belajar Fisika melalui pemahaman konsep tentang Teori Kinetik Gas dengan Metode Diskusi dan Tanya Jawab pada siswa Kelas XI IPA sehingga mereka menjadi termotivasi untuk belajar.

Upaya meningkatkan hasil belajar Fisika melalui pemahaman konsep tentang Teori Kinetik Gas dengan Metode Diskusi dan Tanya Jawab pada siswa Kelas XI IPA memiliki dampak positif terhadap peningkatan prestasi belajar siswa, dimana siswa yang lebih mampu dalam suatu kelompok akan mengajari temanya yang kurang mampu dalam kelompoknya bisa juga antar kelompok

Pernyataan siswa antara lain : dengan Metode Diskusi dan Tanya Jawab pada siswa Kelas XI lebih memudahkan pemahaman suatu materi yang di terima dari guru.

Dengan adanya Upaya meningkatkan Hasil Belajar Fisika melalui pemahaman konsep tentang Teori Kinetik Gas dengan Metode Diskusi dan Tanya Jawab pada siswa Kelas XI IPA sehingga saya lebih mudah memahami materi dan merasa leluasa bertanya sama kawan sekelompok bisa juga saya lakukan antar kelompok menanyakan masalah yang dihadapinya sehingga suasana belajar menjadi aktif serta termotivasi untuk belajar secara berkesinambungan.

Setelah diterapkan Upaya meningkatkan Hasil Belajar Fisika melalui pemahaman konsep tentang Teori Kinetik Gas dengan Metode Diskusi dan Tanya Jawab pada siswa Kelas XI IPA sehingga nilai ulangan remidial sekali tuntas

\section{Daftar Pustaka}

Arikunto, Suharsimi. 2002. Prosedur Penelitian Suatu Pendekatan Praktek. Jakarta: Rineksa Cipta

Ali, Muhammad. 1996. Guru Dalam Proses Belajar Mengajar. Bandung: Sinar Baru Algesindon.

Melvin, L. Siberman. 2004. Aktif Learning, 101 Cara Belajar Siswa Aktif. Bandung: Nusamedia dan Nuansa.

Sukmadinata, Nana Syaodih. 2002. Metode Penelitian Pendidikan. Bandung: PT. Remaja Rosdakarya 
Hendayana, dkk. 2006. Lesson Studi: Suatu Strategi untuk Meningkatkan Keprofesionalan Pendidik. Bandung: UPI PRESS.

Hendayana, S dkk. 2007. Lesson Study Suatu Strategi Untuk Meningkatkan Keprofesionalan Pendidik (Pengalaman Imstep-Jica). Bandung : FPMIPA UPI dan JICA.

Rustaman, N dkk.(2005). Strategi Belajar Mengajar Biologi. Malang: Universitas Negeri Malang.

Slamet Mulyana. 2007. Lesson Study (Makalah). Kuningan: LPMP-Jawa Barat

Sriyati, S. 2005. Reformasi Sekolah melalui Lesson Study. Makalah pada seminar Nasional Pendidikan IPA II dengan tema Membangun Pendidikan IPA Masa Depan yang Kompetitif. 22-23 Juli 2005 di FPMIPA UPI Bandung. 